\title{
Synthesis, characterisation and in vitro antitumour potential of novel Pt(II) estrogen linked complexes
}

\author{
Eolann Kitteringham ${ }^{\mathrm{a}}$, Emma Andriollo ${ }^{\mathrm{b}}$, Valentina Gandin ${ }^{\mathrm{b}}$, Diego Montagner ${ }^{\mathrm{c}}$, \\ Darren M. Griffith ${ }^{\mathrm{a}, *}$ \\ ${ }^{a}$ Department of Chemistry, RCSI, 123 St. Stephens Green, Dublin 2, Ireland \\ ${ }^{\mathrm{b}}$ Dipartimento di Scienze del Farmaco, Università di Padova, Via Marzolo 5, 35131 Padova, Italy \\ ${ }^{\mathrm{c}}$ Department of Chemistry, Maynooth University, Maynooth, Co. Kildare, Ireland
}

\section{A R T I C L E IN F O}

\section{Keywords:}

Platinum

Steroid

Estradiol

Click chemistry

Triazole

In vitro cytotoxicity

Spheroid

\begin{abstract}
A B S T R A C T
The $\mathrm{Cu}(\mathrm{I})$ alkyne azide click reaction of $17 \alpha$-ethynylestradiol and di-tert-butyl (2-azidopropane-1,3-diyl)dicarbamate afforded the novel 1,4 disubstituted 1,2,3 triazole and estrogen-based ligand 2-(4-(estradiol)- $1 \mathrm{H}$ 1,2,3-triazol-1-yl)propane-1,3-diamine, EDiolDap. Reaction of EDiolDap with Pt(II) DMSO precursors, cis$\left[\mathrm{PtCl}_{2}(\mathrm{DMSO})_{2}\right]$ and cis-[Pt(CBDCA $\left.)(\mathrm{DMSO})_{2}\right]$ gave the corresponding Pt(II) estrogen linked complexes $\left[\mathrm{PtCl}_{2}\right.$ (EDiolDap)] and [Pt(CBDCA)(EDiolDap)] respectively in good yield. Both Pt(II) estrogen linked complexes exhibited superior activity as compared to cisplatin and carboplatin in 2D culture and exhibited ca. 30 fold higher activity, in terms of IC $_{50}$ values, against ER + cancer cells (cervical, breast and ovarian) as compared to the reference $\mathrm{ER}$ - colon cancer line. [ $\mathrm{PtCl}_{2}$ (EDiolDap)] and [Pt(CBDCA)(EDiolDap)] retained their anti-tumour activity in an ovarian 3D spheroid culture model and reduced the viability of ovarian cancer cell spheroids ca. 9fold and 5-fold better, respectively, as compared to cisplatin.
\end{abstract}

\section{Introduction}

Cisplatin (Fig. 1) was approved by the US Food and Drug Administration for the treatment of testicular and ovarian cancers in December 1978 [1], thanks to Barnet Rosenberg and his team's commendable scientific curiosity and endeavour. Subsequently over 40 years of concerted and systematic effort have culminated in the approval of two additional Pt-based drugs worldwide (carboplatin and oxaliplatin, Fig. 1) and four nationally (heptaplatin, lobaplatin, miriplatin, and nedaplatin) [2] together with the vast array of unrealised Pt-based drug candidates reported in the literature.

The cytotoxicity of Pt anticancer drugs is primarily associated with the ability of their electrophilic Pt(II) centres to covalently bind to nuclear DNA. The resulting DNA adducts are believed to generate DNA damage responses and ultimately induce apoptosis $[3,4]$. More recently interest has grown in the non-nuclear effects of Pt based drugs given Pt (II) centres also react with cytoplasmic nucleophiles, including mitochondrial DNA, RNA and multiple mitochondrial and extramitochondrial proteins $[5,6]$. Remarkably, oxaliplatin, which is usually used clinically as part of a regimen with folinic acid and 5-fluorouracil to treat stage III colorectal cancer, has been shown to induce immunogenic cell death and ribosome biogenesis stress related cell death
[7-9].

Efforts to curtail the side effects of and vanquish resistance (intrinsic and acquired) to Pt-based anticancer chemotherapeutics continue to drive research focussed on the development of novel Pt-based drug candidates.

Numerous classes of Pt(II) and Pt(IV)-based drug candidates have been specifically designed to target cancers, primarily by conjugating biomolecules that have high binding affinities for receptors prevalent in the desired tissue type [10].

The activity of estrogen, the primary female sex hormone, is mediated by the presence of estrogen receptors (ERs) in cells. ERs are over-expressed in breast, ovarian, colon and prostate cancers, which are termed ER +. ERs therefore represent interesting anticancer targets. In turn a host of strategies have been employed to date where derivatives of one of the three major endogenous estrogens (estrone, estradiol, and estriol) have been chemically linked to for example anticancer drug molecules [10,11], radiopharmaceuticals [12] and fluorescent probes [13] amongst others.

Numerous Pt steroid linked complexes have been developed to date where steroids or their derivatives are bonded to either a mono-, di- or tridentate amino carrier ligand or a labile dicarboxylato ligand, Fig. 2[10,11,14].

\footnotetext{
* Corresponding author.

E-mail address: dgriffith@rcsi.ie (D.M. Griffith).
} 


$$
\begin{aligned}
& \mathrm{H}_{3} \mathrm{~N} \\
& \mathrm{H}_{3} \mathrm{~N}^{-} \mathrm{Pt}=
\end{aligned}
$$

(a)

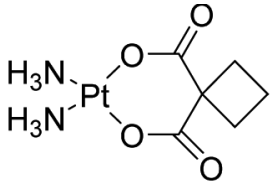

(b)

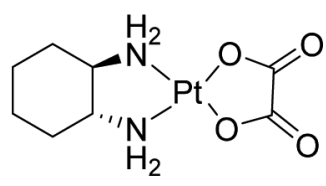

(c)
Fig. 1. Structures of (a) cisplatin (cis- $\left.\left[\mathrm{PtCl}_{2}\left(\mathrm{NH}_{3}\right)_{2}\right]\right)$, (b) carboplatin ([Pt $\left.(\mathrm{CBDCA})\left(\mathrm{NH}_{3}\right)_{2}\right], \mathrm{CBDCA}=$ cyclobutane-1,1-dicarboxylato) and (c) oxaliplatin $([\mathrm{Pt}(\mathrm{DACH})(\mathrm{Ox})](\mathrm{DACH}=1 R, 2 R$ diaminocyclohexane, $\mathrm{Ox}=$ oxalato $)$.

Many of the Pt estrogen-linked complexes described in the literature display good ER binding affinity and have exhibited superior in vitro cytotoxicity than cisplatin for example in ER + cell lines such as the MCF-7 breast cancer cell line, though not in ER- cell lines [10,11,14].

We are interested in the functionalisation of Pt based complexes $[19,20]$ and more recently in the development of click-based conjugation strategies $[21,22]$. The $\mathrm{Cu}(\mathrm{I})$ catalysed azide-alkyne cycloaddition (CuAAC), Fig. 3, which generates the corresponding 1,4-disubstituted 1,2,3-triazole with excellent selectivity and in high yield, is synonymous with 'click chemistry'. To the best of our knowledge there are no examples in the literature where click chemistry is employed to develop a steroid linked ligand for an anticancer Pt drug candidate.

We describe within the synthesis, characterisation and in vitro antitumour potential of novel dichlorido and cyclobutanedicarboxylato Pt (II) estrogen linked complexes both in 2D and 3D cell culture models of $\mathrm{ER}+$ and ER- cancer cells.

\section{Experimental}

\subsection{Materials}

All commercially available reagents and solvents were purchased from Sigma Aldrich and used as supplied (Sigma Aldrich Ireland Ltd., Arklow, Co Wicklow) unless stated otherwise. Sodium azide and $17 \alpha-$ ethynylestradiol were sourced from TCI chemicals (Tokyo Chemical Industry UK Ltd., Oxford, UK) and $\mathrm{K}_{2} \mathrm{PtCl}_{4}$ was sourced from Alfa Chemicals (Alfa Chemicals Ltd, Binfield, Bracknell, UK). Di-tert-butyl (2-azidopropane-1,3-diyl)dicarbamate [23], cis-[Pt(CBDCA)(DMSO) $\left.)_{2}\right]$ [24] and cis-[ $\left.\mathrm{PtCl}_{2}(\mathrm{DMSO})_{2}\right]$ [25] were synthesized as previously reported.

\subsection{Synthetic methods}

Infrared spectroscopy (IR) measurements were obtained using a Nicolet iS10 FT-IR (Thermo Fisher Scientific, Waltham, Massachusetts, USA). The infrared spectra were recorded from 400 to 4000 wavenumbers $\left(\mathrm{cm}^{-1}\right)$ and analysed using $\mathrm{OMNIC}^{\mathrm{TM}}$ software (ver. 9.6, Thermo Fisher Sceintific). ${ }^{1} \mathrm{H}$ NMR spectra were recorded on a Bruker Avance 400 NMR spectrometer. The spectra were analysed using MestReNova software. The residual undeuterated solvent signals were used as an internal reference [26]. ${ }^{195} \mathrm{Pt}$ NMR spectra were recorded on a Bruker $500 \mathrm{AR}$ spectrometer and $\mathrm{K}_{2} \mathrm{PtCl}_{6}$ in $\mathrm{D}_{2} \mathrm{O}$ was used as an external standard. Mass spectrometry experiments were performed on an Advion Expression Compact Mass Spectrometer where $10 \mu \mathrm{L}$ of the samples were injected in 300 $\mu \mathrm{L}$ of methanol:water:formic acid (90:9:1 $\mathrm{v} / \mathrm{v}$ ). The mass spectrometry data were acquired both in positive and negative ion modes and the spectra analysed using the Advion Mass Express software programme.

Elemental analysis ( $\mathrm{C}, \mathrm{H}, \mathrm{N}$ and $\mathrm{Cl}$ ) was performed at the Microanalytical Laboratory, School of Chemistry and Chemical Biology, University College Dublin, Ireland.

\subsection{Syntheses}

2.3.1. Synthesis of di-tert-butyl (2-(4-(estradiol)-1H-1,2,3-triazol-1-yl) propane-1,3-diyl)dicarbamate 1

$17 \alpha$-Ethynylestradiol $(0.400 \mathrm{~g}, 1.349 \mathrm{mmol})$ and di-tert-butyl (2azidopropane-1,3-diyl)dicarbamate $(0.425 \mathrm{~g}, 1.349 \mathrm{mmol})$ were dissolved in 4:1 $\mathrm{H}_{2} \mathrm{O}: \mathrm{MeOH}(50 \mathrm{~mL}) . \mathrm{CuSO}_{4} \cdot 5 \mathrm{H}_{2} \mathrm{O}(0.034 \mathrm{~g}, 0.135 \mathrm{mmol})$ and sodium ascorbate $(0.534 \mathrm{~g}, 2.698 \mathrm{mmol})$ in water $(10 \mathrm{~mL})$ were added and the reaction was stirred for 2 days at $40{ }^{\circ} \mathrm{C}$. The reaction was quenched with saturated ammonium chloride $(40 \mathrm{~mL})$ and extracted into EtOAC $(3 \times 70 \mathrm{~mL})$. The organic layer was washed with brine $(70 \mathrm{~mL})$, dried over $\mathrm{Na}_{2} \mathrm{SO}_{4}$, filtered and concentrated under reduced pressure. The crude product was subject to column chromatography on silica using 9:1 DCM:MeOH to yield $\mathbf{1}$ as a yellow crystalline solid (800 mg, 97\%).

${ }^{1} \mathrm{H}$ NMR (400 MHz, $\mathrm{CDCl}_{3}$ ) $\delta: 7.65$ (bs, $\left.1 \mathrm{H}\right), 6.98$ (bs, 1H), $6.56(\mathrm{~m}$, $2 \mathrm{H}), 5.58(\mathrm{~m}, 2 \mathrm{H}), 4.65(\mathrm{~m}, 1 \mathrm{H}), 3.78(\mathrm{~m}, 2 \mathrm{H}), 3.54(\mathrm{~m}, 2 \mathrm{H}), 3.17(\mathrm{~m}$, $1 \mathrm{H}), 2.74(\mathrm{~m}, 2 \mathrm{H}), 2.35\left(\mathrm{~m},{ }^{3} \mathrm{~J}=18.3 \mathrm{~Hz}, 1 \mathrm{H}\right), 2.09(\mathrm{~m}, 1 \mathrm{H}), 1.88(\mathrm{~m}$, $J=12.6 \mathrm{~Hz}, 3 \mathrm{H}), 1.55(\mathrm{~m}, J=28.2 \mathrm{~Hz}, 3 \mathrm{H}), 1.42$ (bs, $J=4.2 \mathrm{~Hz}$, 22H), $1.02(\mathrm{~s}, 3 \mathrm{H}), 0.60(\mathrm{~m}, 1 \mathrm{H}) \mathrm{ppm} .{ }^{13} \mathrm{C} \mathrm{NMR}\left(101 \mathrm{MHz}, \mathrm{CDCl}_{3}\right) \delta$ : 207.5, 156.7, 153.9, 138.2, 132.1, 126.4, 115.5, 113.0, 80.3, 60.6, 53.6, 48.6, 43.3, 41.3, 41.1, 39.5, 33.1, 31.1, 29.8, 28.4, 27.4, 26.3,

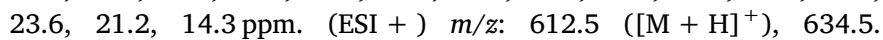
$\left([\mathrm{M}+\mathrm{Na}]^{+}\right)$.

2.3.2. Synthesis of 2-(4-(estradiol)-1H-1,2,3-triazol-1-yl)propane-1,3diamine dihydrochloride 2

$6 \mathrm{M} \mathrm{HCl}(5 \mathrm{~mL})$ was added to $1(0.800 \mathrm{~g}, 1.31 \mathrm{mmol})$ dissolved in EtOAc $(5 \mathrm{~mL})$. The solution was stirred at $\mathrm{rt}$ for $2 \mathrm{~h}$ and stored at $-18^{\circ} \mathrm{C}$ for $4 \mathrm{~h}$. The resultant white precipitate was vacuum filtered and washed with EtOAc to yield 2 as a white solid $(0.604 \mathrm{~g}, 95 \%)$.

${ }^{1} \mathrm{H}$ NMR (400 MHz, $\left.\mathrm{D}_{2} \mathrm{O}\right) \delta: 8.06(\mathrm{~s}, 1 \mathrm{H}), 7.12\left(\mathrm{~d},{ }^{3} \mathrm{~J}=8.2 \mathrm{~Hz}, 1 \mathrm{H}\right)$, $6.61\left(\mathrm{~d},{ }^{3} J=8.2 \mathrm{~Hz}, 2 \mathrm{H}\right), 5.29\left(\mathrm{td},{ }^{3} J=9.1,{ }^{4} J=4.4 \mathrm{~Hz}, 1 \mathrm{H}\right), 3.72$ (ddd, $\left.{ }^{3} J=13.2,{ }^{4} J=9.3,3.6 \mathrm{~Hz}, 2 \mathrm{H}\right), 3.63\left(\mathrm{dd},{ }^{3} J=13.5,{ }^{4} \mathrm{~J}=3.7 \mathrm{~Hz}\right.$, $2 \mathrm{H}), 2.74\left(\mathrm{~d},{ }^{3} \mathrm{~J}=5.6 \mathrm{~Hz}, 2 \mathrm{H}\right), 2.43-2.32(\mathrm{~m}, 1 \mathrm{H}), 2.17-2.05(\mathrm{~m}$, $1 \mathrm{H}), 1.95-1.81$ (m, 3H), $1.66-1.48(\mathrm{~m}, 3 \mathrm{H}), 1.47-1.32(\mathrm{~m}, 2 \mathrm{H}), 1.32$ - 1.11 (m, 2H), 0.97 (s, 3H), 0.78 (t, $\left.{ }^{3} J=12.7,{ }^{4} J=9.0 \mathrm{~Hz}, 1 \mathrm{H}\right) \mathrm{ppm}$. ${ }^{13} \mathrm{C}$ NMR $\left(101 \mathrm{MHz}, \mathrm{D}_{2} \mathrm{O}\right) \delta: 154.4,153.2,138.9,132.6,126.7,124.0$, $115.3,112.9,82.7,56.6,47.9,46.9,42.7,40.7,40.6,38.9,36.7,32.2$, 28.9, 26.8, 25.6, 22.9, $13.7 \mathrm{ppm}$. (ESI+) $\mathrm{m} / z:([\mathrm{M}-2 \mathrm{Cl}]) 413.5$.

\subsubsection{Synthesis of $\left[\mathrm{PtCl}_{2}\right.$ (EDiolDap)] 3}

DBU $(70.9 \mu \mathrm{L}, 0.474 \mathrm{mmol})$ was added to $2(0.114 \mathrm{~g}, 0.237 \mathrm{mmol})$ dissolved in DMF (1 mL). The resultant solution was added dropwise to cis-[ $\left.\mathrm{PtCl}_{2}(\mathrm{DMSO})_{2}\right](0.100 \mathrm{~g}, 0.237 \mathrm{mmol})$ dissolved in DMF $(1 \mathrm{~mL})$. The reaction was stirred at $\mathrm{rt}$ for 2 days. Water $(3 \mathrm{~mL})$ was added to the flask resulting in the precipitation of an off white solid. The solution was cooled to $4{ }^{\circ} \mathrm{C}$ for $4 \mathrm{~h}$. The precipitate was vacuum filtered and washed with water and $\mathrm{Et}_{2} \mathrm{O}$ and dried over $\mathrm{P}_{2} \mathrm{O}_{5}$ to give 4 as a brown solid (92.9 mg, 58\%). EA calc. \% for $\mathrm{C}_{23} \mathrm{H}_{33} \mathrm{Cl}_{2} \mathrm{~N}_{5} \mathrm{O}_{2} \mathrm{Pt} \cdot 0.25 \mathrm{H}_{2} \mathrm{O}$ requires C, 40.50; H, 4.95; N, 10.27; Cl, 10.40, found C, 40.71; H, 5.32; N, 10.41; $\mathrm{Cl} 10.17 \% .{ }^{1} \mathrm{H}$ NMR (400 MHz, DMF- $\left.d_{7}\right) \delta: 9.17(\mathrm{~s}, 1 \mathrm{H}), 8.12(\mathrm{~s}, 1 \mathrm{H})$, $7.02\left(\mathrm{~d},{ }^{3} J=12 \mathrm{~Hz}, 1 \mathrm{H}\right), 6.58$ (d, $\left.J=12 \mathrm{~Hz}, 1 \mathrm{H}\right), 6.55$ (s, $\left.1 \mathrm{H}\right), 5.60$ (bs, 2H), 5.51 (bs, 2H), $5.16(\mathrm{~s}, 1 \mathrm{H}), 5.07\left(\mathrm{t},{ }^{3} J=8 \mathrm{~Hz}, 1 \mathrm{H}\right), 3.58(\mathrm{~m}, 1 \mathrm{H})$, $3.33(\mathrm{~m}, 2 \mathrm{H}), 3.08\left(\mathrm{~d},{ }^{3} \mathrm{~J}=8 \mathrm{~Hz}, 2 \mathrm{H}\right), 2.41(\mathrm{~m}, 1 \mathrm{H}), 2.05(\mathrm{~m}, 3 \mathrm{H}), 1.73$ $(\mathrm{m}, 6 \mathrm{H}), 1.25(\mathrm{~m}, 6 \mathrm{H}), 0.67\left(\mathrm{t},{ }^{3} J=12 \mathrm{~Hz}, 1 \mathrm{H}\right) \mathrm{ppm} .{ }^{195} \mathrm{Pt}$ NMR $\left(86 \mathrm{MHz}, \quad\right.$ DMSO- $\left.d_{6}\right) \quad \delta: \quad-2277.74 \mathrm{ppm}$. ESI-MS (+ve): $\mathrm{m} / \mathrm{z}$ $(\mathrm{M}-\mathrm{Cl}+\mathrm{DMSO})$ 720.5. FT-IR $\nu_{\max }\left(\mathrm{cm}^{-1}\right): 3189,3120,2925,2871$, $1652,1609,1498,1436,1386,1288,1251,1224,1131,1098,1060$, 1024, 913, 871, 819, 787, 661 .

\subsubsection{Synthesis of [Pt(CBDCA)(EDiolDap)] 4}

$\mathrm{NaOH}(0.019 \mathrm{~g}, 0.480 \mathrm{mmol})$ in water $(5 \mathrm{~mL})$ was added to 2 $(0.116 \mathrm{~g}, 0.240 \mathrm{mmol})$ dissolved in DMF $(1 \mathrm{~mL})$. The resultant solution was added dropwise to cis-[Pt(CBDCA)(DMSO) $\left.{ }_{2}\right](0.114 \mathrm{~g}, 0.240 \mathrm{mmol})$ dissolved in water $(10 \mathrm{~mL})$ at $100{ }^{\circ} \mathrm{C}$. The reaction was stirred at $100{ }^{\circ} \mathrm{C}$ 


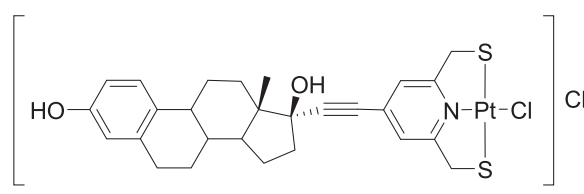

(a)

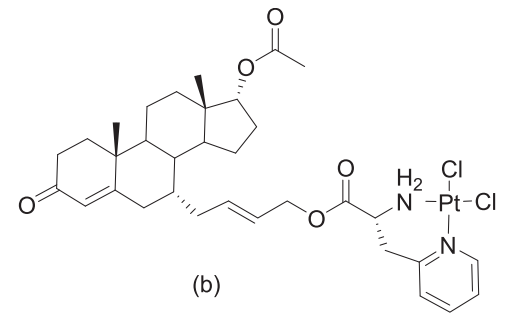

(b)

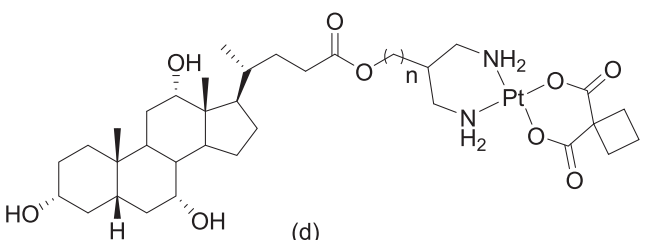<smiles>C[C@@]12CCC3c4ccc(OC(=O)c5ccccc5)cc4CCC3C1CC2</smiles>

c)<smiles>CCC(C)OC(=O)NNC(=O)CCC(=O)OP(N)(N)(N)Cl</smiles><smiles>CCOP(N)(N)(Cl)OC(=O)CCC(=O)NNC(=O)O[C@H]1CCC2C3CCc4cc(OC(=O)c5ccccc5)ccc4C3CC[C@@]21C</smiles>

(e)

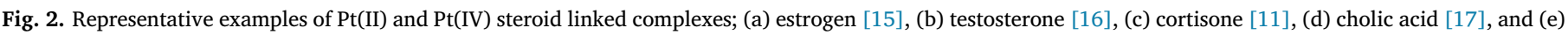
estrogen [18].

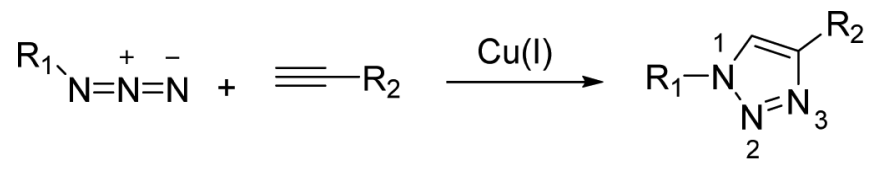

Fig. 3. Copper(I) catalysed azide alkyne 1,3-dipolar cycloaddition reaction between azides and terminal alkynes.

for $6 \mathrm{~h}$. A precipitate was vacuum filtered and washed with water, EtOH and $\mathrm{Et}_{2} \mathrm{O}$ to give 4 as a white solid $(0.133 \mathrm{~g}, 74 \%)$. EA calc. \% for $\mathrm{C}_{29} \mathrm{H}_{39} \mathrm{O}_{6} \mathrm{~N}_{5} \mathrm{Pt} \cdot 1.5 \mathrm{H}_{2} \mathrm{O}$ requires $\mathrm{C}, 44.90 ; \mathrm{H}, 5.46 ; \mathrm{N}, 9.03$, found $\mathrm{C}$, 44.75; H, 5.46; N, 9.12\%. ${ }^{1} \mathrm{H}$ NMR (400 MHz, DMSO-d 6 ) $\delta: 8.99(\mathrm{~s}, 1 \mathrm{H})$, $7.98(\mathrm{~s}, 1 \mathrm{H}), 6.95\left(\mathrm{~d},{ }^{3} \mathrm{~J}=8.0 \mathrm{~Hz}, 1 \mathrm{H}\right), 6.45\left(\mathrm{~d},{ }^{3} \mathrm{~J}=8.0 \mathrm{~Hz}, 2 \mathrm{H}\right), 5.48$ (bs, 2H), 5.32 (bs, 2H), 5.20 (s, 1H), 4.58 (t, $\left.{ }^{3} \mathrm{~J}=8.0 \mathrm{~Hz}, 1 \mathrm{H}\right), 2.90$ (m, $2 \mathrm{H}), 2.68(\mathrm{~m}, 3 \mathrm{H}), 2.31(\mathrm{~m}, 2 \mathrm{H}), 2.24\left(\mathrm{t},{ }^{3} \mathrm{~J}=8 \mathrm{~Hz}, 2 \mathrm{H}\right), 2.07(\mathrm{~m}, 2 \mathrm{H})$, $1.74(\mathrm{~m}, 7 \mathrm{H}), 1.60(\mathrm{~m}, 2 \mathrm{H}), 1.40(\mathrm{~m}, 3 \mathrm{H}), 1.28(\mathrm{~m}, 2 \mathrm{H}), 1.16(\mathrm{~m}, 2 \mathrm{H})$, $0.49\left(\mathrm{t},{ }^{3} \mathrm{~J}=8 \mathrm{~Hz}, 1 \mathrm{H}\right) \quad \mathrm{ppm} .{ }^{195} \mathrm{Pt}$ NMR $\left(86 \mathrm{MHz}\right.$, DMSO- $\left.d_{6}\right) \delta$ : -3245.61 ppm. ESI-MS(-ve): $m / z(M-H)$ 747.0, (M-2xOH) 714.2. FT-IR $\nu_{\max }\left(\mathrm{cm}^{-1}\right): 3384,3195,3116,2932,2870,1648,1609,1585$, 1500, 1448, 1378, 1356, 1289, 1235, 1153, 1053, 1022, 913, 870, 847, 787.

\subsection{Biological studies}

Pt(II) complexes, 3 and 4, were dissolved in minimum DMSO directly prior to testing. A calculated amount of the stock drug DMSO solution was added to the cell culture medium to give a final maximum DMSO concentration of $0.5 \%$, which had no effects on cell viability. Cisplatin and carboplatin were dissolved in $0.9 \%$ sodium chloride solution. MTT (3-(4,5-dimethylthiazol-2-yl)- 2,5-diphenyltetrazolium bromide), cisplatin, carboplatin and ImmunoPure p-nitrophenyl phosphate (APH) were obtained from Sigma Chemical Co, St. Louis, USA.

\subsubsection{Cell cultures}

Human colon (HCT-15) and breast (MCF-7) carcinoma cell lines were obtained from American Type Culture Collection (ATCC, Rockville, MD). Human ovarian 2008 cancer cells were kindly provided by Prof. G. Marverti (Dept. of Biomedical Science of Modena University, Italy). Human ovarian A2780 cancer cells were kindly provided by Prof. M.P.Rigobello (Dept. of Biomedical Science of Padova University, Italy). Human squamous cervical A431 carcinoma cells were kindly provided by Prof. F. Zunino (Division of Experimental Oncology B, Istituto Nazionale dei Tumori, Milan, Italy). Cell lines were maintained in the logarithmic phase at $37^{\circ} \mathrm{C}$ in a $5 \%$ carbon dioxide atmosphere using RPMI-1640 medium (Euroclone) containing 10\% foetal calf serum (Euroclone, Milan, Italy), antibiotics (50 units/mL penicillin and $50 \mu \mathrm{g} / \mathrm{mL}$ streptomycin), and $2 \mathrm{mM}$ l-glutamine.

\subsubsection{Spheroid cultures}

Spheroids were initiated in liquid overlay by seeding $1.5 \times 10^{3}$ A2780 cells/well in phenol red free RPMI-1640 medium (Sigma Chemical Co.), containing 10\% FCS and supplemented with $20 \%$ methyl cellulose stock solution. A total of $150 \mu \mathrm{L}$ of this cell suspension was transferred to each well of a round bottom non-tissue culture treated 96 well-plate (Greiner Bio-one, Kremsmünster, Austria) to allow spheroid formation within $72 \mathrm{~h}$.

\subsubsection{Cytotoxicity assays}

2.4.3.1. MTT assay. The growth inhibitory effect towards adherent cancer cell lines was evaluated by means of MTT assay [27]. Briefly, $3-8 \times 10^{3}$ cells/well, dependent upon the growth characteristics of the cell line, were seeded in 96-well microplates in growth medium $(100 \mu \mathrm{L})$. After $24 \mathrm{~h}$, the medium was removed and replaced with fresh media containing the compound to be studied at the appropriate concentration. Triplicate cultures were established for each treatment. After $72 \mathrm{~h}$, each well was treated with $10 \mu \mathrm{L}$ of a $5 \mathrm{mg} / \mathrm{mL}$ MTT saline solution, and after additional $5 \mathrm{~h}$ of incubation, $100 \mu \mathrm{L}$ of a sodium dodecylsulfate (SDS) solution in $\mathrm{HCl} 0.01 \mathrm{M}$ were added. Following an overnight incubation, cell growth inhibition was detected by measuring the absorbance of each well at $570 \mathrm{~nm}$ using a Bio-Rad 680 microplate reader. Mean absorbance for each drug dose was expressed as a percentage of the absorbance of the untreated control well and plotted vs drug concentration. IC $_{50}$ values, the drug concentrations that reduce the mean absorbance at $570 \mathrm{~nm}$ to $50 \%$ of those in the untreated control wells, were calculated by four parameters logistic (4- 
PL) model. All the values are the means \pm SD of not less than five measurements starting from three different cell cultures.

2.4.3.2. Acid phosphatase (APH) assay. An APH modified assay was used for determining cell viability in 3D spheroids. Briefly, the preseeded spheroids were treated with fresh medium containing the compound to be studied at the appropriate concentration. Triplicate cultures were established for each treatment. After $72 \mathrm{~h}$, each well was treated with $100 \mu \mathrm{L}$ of the assay buffer $(0.1 \mathrm{M}$ sodium acetate, $0.1 \%$ Triton-X-100, supplemented with ImmunoPure $p$-nitrophenyl phosphate) and, following $3 \mathrm{~h}$ of incubation, $10 \mu \mathrm{L}$ of $1 \mathrm{M} \mathrm{NaOH}$ solution were added. The inhibition of the cell growth induced by the tested complexes was detected by measuring the absorbance of each well at $405 \mathrm{~nm}$, using a Bio-Rad 680 microplate reader. Mean absorbance for each drug dose was expressed as a percentage of the untreated control well absorbance $(\mathrm{T} / \mathrm{C})$ and plotted vs drug concentration. $\mathrm{IC}_{50}$ values, the drug concentrations that reduce the mean absorbance at $405 \mathrm{~nm} \mathrm{50 \%} \mathrm{of} \mathrm{those} \mathrm{in} \mathrm{the} \mathrm{untreated} \mathrm{control}$ wells, were calculated by four parameter logistic (4-PL) model. Evaluation was based on means from at least four independent experiments.

\section{Results and discussion}

\subsection{Synthesis of 2-(4-(estradiol)-1H-1,2,3-triazol-1-yl)propane-1,3-} diamine dihydrochloride 2

(2-(4-(estradiol)-1H-1,2,3-triazol-1-yl)propane-1,3-diamine) dihydrochloride 2 was synthesised in two steps, Scheme 1, in line with previous reports [21-23].

In the first step, the CuAAC reaction of $17 \alpha$-ethynylestradiol and ditert-butyl (2-azidopropane-1,3-diyl)dicarbamate gave the corresponding 1,4 disubstituted 1,2,3 triazole, di-tert-butyl (2-(4-(estradiol)$1 H$-1,2,3-triazol-1-yl)propane-1,3-diyl)dicarbamate 1 , in $97 \%$ yield. 1 was characterised by ${ }^{1} \mathrm{H}$ and ${ }^{13} \mathrm{C}$ NMR spectroscopy and mass spectrometry, Figs. S1-3, Supplementary Material.

In the ${ }^{1} \mathrm{H}$ NMR spectrum for example key diagnostic signals include those for the single triazole proton at $7.65 \mathrm{ppm}$ and the eighteen tertbutyl protons at $1.42 \mathrm{ppm}$. ESI-MS in positive mode revealed the presence of ions asscociated with $\mathrm{M}+\mathrm{H}$ and $\mathrm{M}+\mathrm{Na}$ at 612.5 and 634.5 a.m.u. respectively.

In the second step, standard BOC deprotection of the diamine groups in 1 using $\mathrm{HCl}$ afforded the corresponding $\mathrm{HCl}$ salt, 2-(4-(estradiol)-1H-1,2,3-triazol-1-yl)propane-1,3-diamine dihydrochloride 2 in $95 \%$ yield. 2 was characterised by ${ }^{1} \mathrm{H}$ and ${ }^{13} \mathrm{C}$ NMR spectroscopy and mass spectrometry, Figs. S4-6, Supplementary Material. The ${ }^{1} \mathrm{H}$ NMR spectrum of 2 in $\mathrm{D}_{2} \mathrm{O} 15$ signals are associated with 27 protons. Protons associated with the two amine groups $(6 \times \mathrm{H})$ and the two hydroxyl protons are not present as expected. The single triazole proton is found at $8.06 \mathrm{ppm}$. ESI-MS in positive mode aided the identification of the $\mathrm{M}-2 \mathrm{Cl}$ product ion fragments at 413.5 a.m.u.

\subsection{Synthesis of Pt estradiol complexes.}

Pt(II) estradiol complexes were synthesised on neutralisation of 2-(4(estradiol)-1H-1,2,3-triazol-1-yl)propane-1,3-diamine dihydrochloride 2 with two equivalents of base and subsequent reaction with $\mathrm{Pt}(\mathrm{II}) \mathrm{di}$ methylsulfoxido precursor complexes [24,28].

Reaction of cis-[ $\left[\mathrm{PtCl}_{2}(\mathrm{DMSO})_{2}\right]$ with 2 in the presence of two equivalents of 1,8-diazabiciclo[5.4.0] undek-7-en (DBU) afforded the novel $\mathrm{Pt}(\mathrm{II})$ dichlorido estradiol complex, $\left[\mathrm{PtCl}_{2}\right.$ (EDiolDap)] 3 (Scheme 2) in moderate yield (58\%), where EDiolDap is 2-(4-(estradiol)- $1 \mathrm{H}$ 1,2,3-triazol-1-yl)-propane-1,3-diamine. cis-[ $\left[\mathrm{PtCl}_{2}(\mathrm{DMSO})_{2}\right]$ for example was previously employed as a precursor for the synthesis of diamino platinum(II) complexes of formulae cis-[ $\left[\mathrm{PtCl}_{2}\right.$ (diamine)] [28-30]. 3 was characterized by elemental analysis, ${ }^{1} \mathrm{H}$ and ${ }^{195} \mathrm{Pt}$ NMR spectroscopy and mass spectrometry, Figs. S7-10, Supplementary Material.

Elemental analysis of $\mathbf{3}$ is consistent with two chlorido ligands and one EDiolDap ligand per Pt(II) centre. In the ${ }^{1} \mathrm{H}$ NMR spectrum diagnostic signals for example comprise the triazole proton at $9.17 \mathrm{ppm}$, the three aromatic protons at $8.12,7.02$ and $6.58 \mathrm{ppm}$ and the four amino protons observed at 5.60 and $5.51 \mathrm{ppm}$ as two broad singlets. The remaining twenty five aliphatic protons are accounted for in the complex spectrum, Fig. S7, Supplementary Material. The ${ }^{195} \mathrm{Pt}$ NMR features one signal at $-2277 \mathrm{ppm}$, which is consistent with a $\mathrm{Pt}(\mathrm{II}) \mathrm{N}_{2} \mathrm{Cl}_{2}$ type complex. The ESI MS in positive mode, obtained from a DMSO solution of 3 diluted with $\mathrm{MeOH}$, features a mass at 720.5 a.m.u associated with

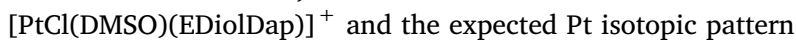

Reaction of cis-[Pt(CBDCA)(DMSO) $\left.)_{2}\right]$ with 2 in the presence of two equivalents of $\mathrm{NaOH}$ afforded the novel Pt(II) 1,1-cyclobutanedicarboxylato estradiol complex, [Pt(CBDCA)(EDiolDap)] $\mathbf{4}$ in good yield (74\%). cis-[Pt(CBDCA)(DMSO $)_{2}$ ] for example was previously employed as a precursor for the synthesis of diamino platinum(II) complexes of formulae cis-[Pt(CBDCA)(diamine)] [24,28,30]. 4 was characterized by elemental analysis, ${ }^{1} \mathrm{H}$ and ${ }^{195} \mathrm{Pt}$ NMR and mass spectrometry. Elemental analysis of 4 is consistent with one 1,1-cyclobutanedicarboxylato ligand and one EDiolDap ligand per Pt(II) centre.

In the ${ }^{1} \mathrm{H}$ NMR spectrum diagnostic signals for example consist of the triazole proton at $8.99 \mathrm{ppm}$, the three aromatic protons at 7.98, 6.95 and $6.45 \mathrm{ppm}$ and the four amino protons at 5.48 and $5.32 \mathrm{ppm}$ as two broad singlets. The remaining thirty one aliphatic protons are
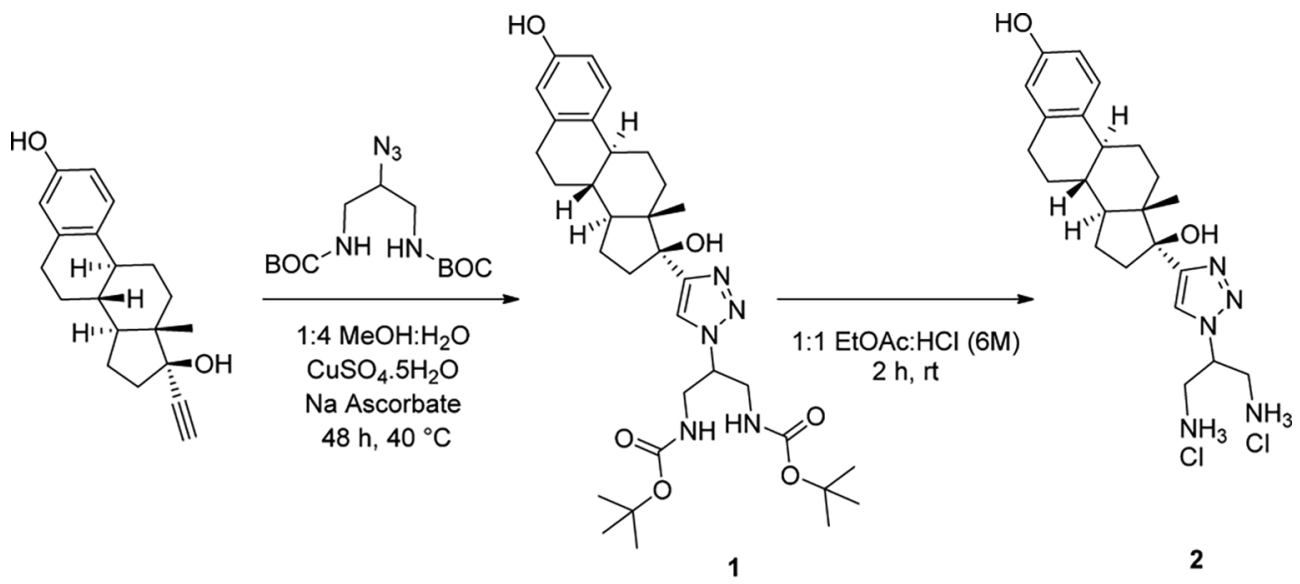

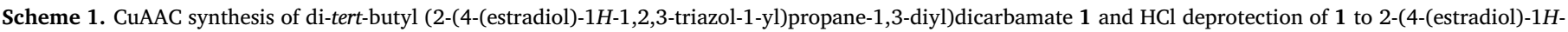
1,2,3-triazol-1-yl)propane-1,3-diamine dihydrochloride 2. 


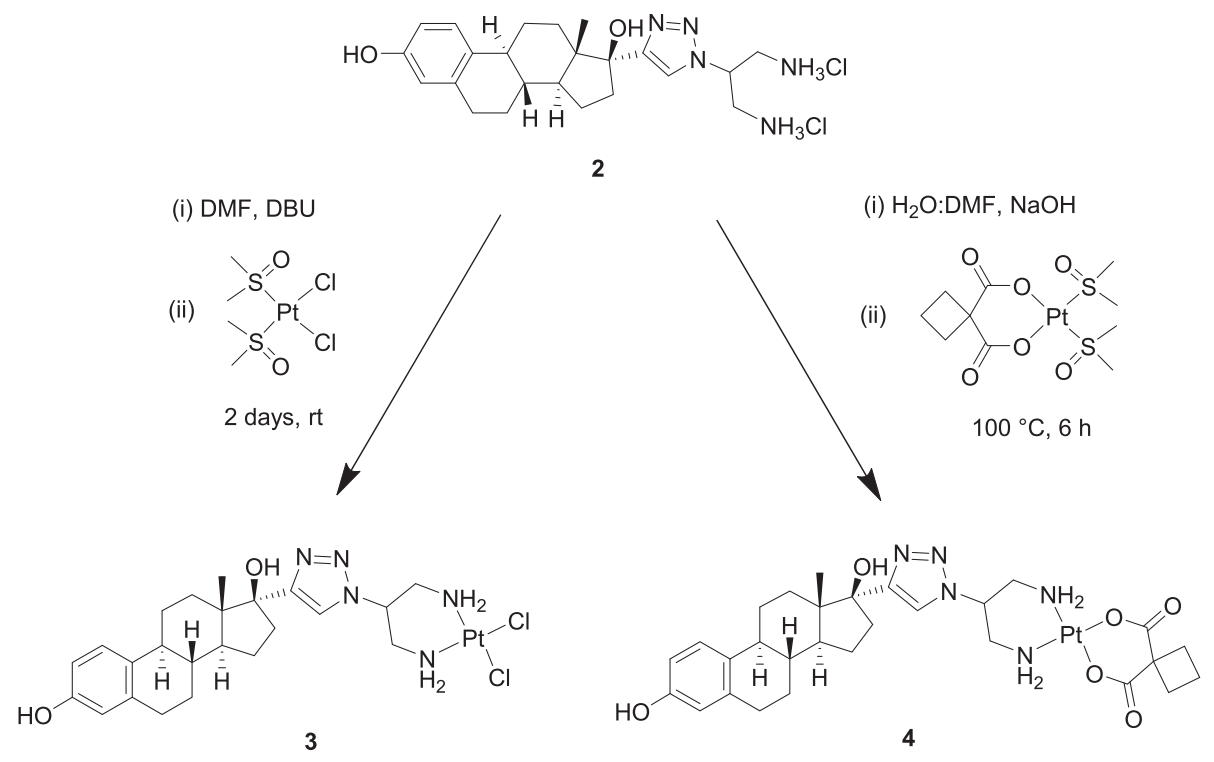

Scheme 2. Synthesis of $\left[\mathrm{PtCl}_{2}\right.$ (EDiolDap)] 3 and [Pt(CBDCA)(EDiolDap)] 4.

accounted for in the complex spectrum, Fig. S11, Supplementary Material. The ${ }^{195} \mathrm{Pt}$ NMR features one signal at $-3245.61 \mathrm{ppm}$, which is consistent with a $\mathrm{Pt}(\mathrm{II}) \mathrm{N}_{2} \mathrm{O}_{2}$ type complex. The ESI MS in negative mode features masses at 747.0 a.m.u associated with $\mathrm{M}-\mathrm{H}$ and 714.2 associated with $\mathrm{M}-2 \mathrm{xOH}$. The expected Pt isotopic pattern is observed.

\subsection{Cytotoxic activity in $2 D$ and $3 D$ cancer cell cultures}

With the aim of evaluating if the newly developed Pt(II) complexes $\mathbf{3}$ and $\mathbf{4}$ are more effective in targeting and affecting the viability of ER + cell lines with respect to ER- ones, their in vitro antitumour potential was assessed in a panel of ER + human cancer cell lines; A431 (cervical), MCF-7 (breast), and 2008 and A2780 (ovarian) cancer cells as well as against ER- HCT-15 colon cancer cells. Cells were exposed to the indicated compounds for $72 \mathrm{~h}$ and the $\mathrm{IC}_{50}$ values, calculated from the dose-response curves, are listed in Table 1.

Both complexes exhibited impressive in vitro cytotoxic activity, superior than those elicited by reference Pt(II) compounds cisplatin and carboplatin, with $\mathrm{IC}_{50}$ values in the low-/sub-micromolar range against all cancer cell lines tested. Compound 3 elicited average $\mathrm{IC}_{50}$ values of $0.035 \mu \mathrm{M}$, up to one order of magnitude higher with respect to complex 4. Remarkably, the $\mathrm{IC}_{50}$ for $\left[\mathrm{PtCl}_{2}\right.$ (EDiolDap)] $(0.01 \mu \mathrm{M})$ against the commonly studied MCF-7 cancer cell line, is remarkably lower than the IC $_{50}$ values associated with previously reported classes of Pt(II) estradiol-linked complexes; 2-4 $\mu \mathrm{M}[31]$, 3-33 $\mu \mathrm{M}$ [32] and > $3 \mu \mathrm{M}$ [33], for example. Both complexes showed greater in vitro cytotoxic activity against ER + cancer cells, where the $\mathrm{IC}_{50}$ values calculated for both derivatives against the ER- colon cancer line HCT-15 were about 30 times higher than those calculated against the in-house ER + panel of cancer cells. This data strongly support the ability of these estradiolbearing Pt(II) complexes to selectively target ER + cancer cell lines.
The in vitro antitumour potential of Pt(II) complexes was also examined in a 3D ovarian cancer cell culture model. 3D spheroid models are more physiologically relevant and predictive compared to $2 \mathrm{D}$ models when screening potential anti-proliferative drug candidates.

Table 2 summarizes the $\mathrm{IC}_{50}$ values obtained after treatment of A2780 cancer cell spheroids with the novel Pt(II) complexes, 3 and 4, and cisplatin, the control Pt(II)-based anticancer drug.

In accordance with 2D tests, complex 3 proved to be the most effective compound, showing an efficacy in decreasing cancer spheroid viability about 9 times higher than that of cisplatin. However, complexes 4 despite being less effective than 3 , it retained an antitumour efficacy in 3D cell system which was about 5 times higher than that of cisplatin.

\section{Conclusion}

Triazoles are ideally suited to build multifunctional ligand systems given the high synthetic flexibility associated with click chemistry. The estrogen based ligand 2-(4-(estradiol)-1H-1,2,3-triazol-1-yl)propane1,3-diamine, EDiolDap was synthesised in good yield by the CuAAC reaction between $17 \alpha$-ethynylestradiol and di-tert-butyl (2-azidopropane-1,3-diyl)dicarbamate. Reaction of EDiolDap with Pt(II) DMSO precursors, cis- $\left[\mathrm{PtCl}_{2}(\mathrm{DMSO})_{2}\right]$ and cis-[Pt(CBDCA)(DMSO $\left.)_{2}\right]$ gave the corresponding $\mathrm{Pt}(\mathrm{II})$ estrogen linked complexes $\left[\mathrm{PtCl}_{2}\right.$ (EDiolDap)] and [Pt(CBDCA)(EDiolDap)] respectively in good yield. The in vitro cytotoxicity of both estrogen linked Pt(II) complexes and cisplatin were investigated against a panel of ER + cancer cell lines (cervical - A431, breast - MCF-7 and ovarian - 2008 and A2780) as well as against an ER- colon cancer cell line, HCT-15. Both complexes exhibited superior in vitro cytoxicity than cisplatin against all of the cancer cell lines tested. $\left[\mathrm{PtCl}_{2}\right.$ (EDiolDap)] exhibited approximately an order of magnitude

Table 1

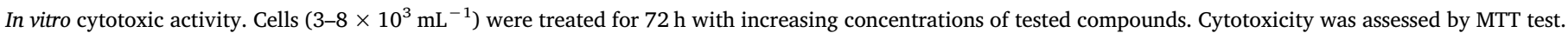
IC $_{50}$ values $(\mu \mathrm{M})$ were calculated by a four parameter logistic model $(P<0.05)$. S.D. $=$ standard deviation.

\begin{tabular}{|c|c|c|c|c|c|}
\hline & \multicolumn{5}{|l|}{$\mathrm{IC}_{50} \pm$ S.D. } \\
\hline & A2780 & 2008 & A431 & MCF-7 & HCT-15 \\
\hline 3 & $0.01 \pm 0.003$ & $0.09 \pm 0.01$ & $0.03 \pm 0.01$ & $0.01 \pm 0.004$ & $0.4 \pm 0.1$ \\
\hline 4 & $0.1 \pm 0.02$ & $0.7 \pm 0.3$ & $0.5 \pm 0.1$ & $0.3 \pm 0.06$ & $1.8 \pm 0.4$ \\
\hline Cisplatin & $2.6 \pm 0.8$ & $2.2 \pm 0.6$ & $1.7 \pm 0.3$ & $7.6 \pm 0.2$ & $13.9 \pm 1.7$ \\
\hline Carboplatin & $3.6 \pm 1.2$ & $5.8 \pm 1.4$ & $12.3 \pm 3.3$ & $>100$ & $>100$ \\
\hline
\end{tabular}


Table 2

In vitro cytotoxicity against ovarian cancer cell spheroids. Spheroids $\left(1.5 \times 10^{3}\right.$ cells/well $)$ were treated for $72 \mathrm{~h}$ with increasing concentrations of test compounds. The growth inhibitory effect was evaluated by means of the $\mathrm{APH}$ test. $\mathrm{IC}_{50}$ values were calculated from the dose-survival curves by the four parameter logistic model $(\mathrm{P}<0.05)$. $\mathrm{SD}=$ standard deviation.

\begin{tabular}{ll}
\hline & $\begin{array}{l}\text { IC }_{50} \pm \text { S.D. } \\
\text { A2780 }\end{array}$ \\
\hline 3 & $12.4 \pm 1.2$ \\
4 & $20.1 \pm 3.5$ \\
Cisplatin & $111.6 \pm 7.5$ \\
\hline
\end{tabular}

greater in vitro cytotoxic activity than its dicarboxylato analogue, $[\mathrm{Pt}$ (CBDCA)(EDiolDap)]. Interestingly the two estrogen linked Pt(II) complexes showed a ca. 30 times greater in vitro cytotoxic effect against $\mathrm{ER}+$ cancer cell lines as compared to against the ER- colon cancer line HCT-15.

$3 \mathrm{D}$ cell culture is superior to traditional 2D culture at simulating an in vivo environment. It is therefore noteworthy that $\left[\mathrm{PtCl}_{2}\right.$ (EDiolDap)] and $[\mathrm{Pt}(\mathrm{CBDCA})(\mathrm{EDiolDap})]$ retained their anti-tumour activity in an ovarian 3D A2780 spheroid culture model and reduced the viability of the ovarian cancer cell spheroids ca. 9 fold and 5 fold better respectively as compared to the clinically used Pt-based chemotherapeutic, cisplatin.

The functionalisation of Pt based complexes is an important strategy for the development of the next generation of Pt-based anticancer drugs. Though many Pt(II) steroid complexes have been developed to date, this novel class certainly exhibits standout in vitro cytotoxic activity.

\section{Supplementary material}

${ }^{1} \mathrm{H},{ }^{13} \mathrm{C}$ and ${ }^{195} \mathrm{Pt}$ NMR and ESI mass spectra are available to view.

\section{Acknowledgements}

EK sincerely thanks the Royal College of Surgeons in Ireland for financial support through the RCSI Apjohn Scholarship. This publication has emanated from research supported in part by a research grant from Science Foundation Ireland (SFI) and is co-funded under the European Regional Development Fund under Grant Number 12/RC/ 2275_P2.

\section{Appendix A. Supplementary data}

Supplementary data to this article can be found online at https:// doi.org/10.1016/j.ica.2019.05.043.

\section{References}

[1] B. Lippert (Ed.), Cisplatin - Chemistry and Biochemistry of a Leading Anticancer Drug, Wiley-VCH, Weinheim, 1999.

[2] R. Oun, Y.E. Moussa, N.J. Wheate, Dalton Trans. 47 (2018) 6645-6653.

[3] L. Kelland, Nat. Rev. 7 (2007) 573-584.

[4] N.J. Wheate, S. Walker, G.E. Craig, R. Oun, Dalton Trans. 39 (2010) 8113-8127.

[5] L. Galluzzi, I. Vitale, J. Michels, C. Brenner, G. Szabadkai, A. Harel-Bellan, M. Castedo, G. Kroemer, Cell. Death Dis., vol. 5, 2014, pp. e1257.

[6] J.D. White, M.M. Haley, V.J. DeRose, Acc. Chem. Res. 49 (2016) 56-66.

[7] S. Göschl, E. Schreiber-Brynzak, V. Pichler, K. Cseh, P. Heffeter, U. Jungwirth, M.A. Jakupec, W. Berger, B.K. Keppler, Metallomics 9 (2017) 309-322.

[8] P.M. Bruno, Y. Liu, G.Y. Park, J. Murai, C.E. Koch, T.J. Eisen, J.R. Pritchard, Y. Pommier, S.J. Lippard, M.T. Hemann, Nat. Med. 23 (2017) 461-471.

[9] I.A. Riddell, Met. Ions, Life Sci. vol, (2018) 18.

[10] R.G. Kenny, C.J. Marmion, Chem. Rev. 119 (2019) 1058-1137.

[11] F. Le Bideau, S. Dagorne, Chem. Rev. 113 (2013) (2013) 7793-7850.

[12] H.M. Linden, L.M. Peterson, A.M. Fowler, PET clinics 13 (2018) 415-422.

[13] N. Gajadeera, R.N. Hanson, Steroids 144 (2019) 30-46.

[14] P. Zhang, Y.W. Yang, Z.R. Shen, Mini Rev. Med. Chem. 13 (2013) 265-272.

[15] A. Jackson, J. Davis, R.J. Pither, A. Rodger, M.J. Hannon, Inorg Chem 40 (2001) 3964-3973.

[16] S. Fortin, K. Brasseur, N. Morin, E. Asselin, G. Berube, Eur. J. Med. Chem. 68 (2013) 433-443.

[17] R. Paschke, J. Kalbitz, C. Paetz, M. Luckner, T. Mueller, H.J. Schmoll, H. Mueller, E. Sorkau, E. Sinn, J. Inorg. Biochem. 94 (2003) 335-342.

[18] K.R. Barnes, A. Kutikov, S.J. Lippard, Chem. Biol. 11 (2004) 557-564.

[19] A. McKeon, A. Egan, J. Chandanshive, H. McMahon, D. Griffith, Molecules, vol. 21, 2016, pp. 949.

[20] A.M. McKeon, J. Noonan, M. Devocelle, B.M. Murphy, D.M. Griffith, Chem. Commun. 53 (2017) 11318-11321.

[21] E. Kitteringham, Z. Zhou, B. Twamley, D.M. Griffith, Inorg. Chem. 57 (2018) 12282-12290.

[22] E. Kitteringham, D. Wu, S. Cheung, B. Twamley, D.F. O'Shea, D.M. Griffith, J. Inorg Biochem. 182 (2018) 150-157.

[23] D. Urankar, J. Košmrlj, Inorg. Chim. Acta 363 (2010) 3817-3822.

[24] P. Bitha, G.O. Morton, T.S. Dunne, E.F. Delos Santos, Y.I. Lin, S.R. Boone, R.C Haltiwanger, C.G. Pierpont, Inorg. Chem., vol. 29, 1990, pp. 645-652.

[25] V.Y. Kukushkin, A.J.L. Pombeiro, C.M.P. Ferreira, L.I. Elding, Inorg. Synth. 33 (2002) 189-196.

[26] H.E. Gottlieb, V. Kotlyar, A. Nudelman, J. Org. Chem. 62 (1997) 7512-7515.

[27] M.C. Alley, D.A. Scudiero, A. Monks, M.L. Hursey, M.J. Czerwinski, D.L. Fine, B.J. Abbott, J.G. Mayo, R.H. Shoemaker, M.R. Boyd, Cancer Res. 48 (1988) 589-601.

[28] J.J. Wilson, S.J. Lippard, Chem. Rev. 114 (2014) 4470-4495.

[29] B. Aljoša, U. Damijana, K. Janez, Eur. J. Org. Chem. 2014 (2014) 8167-8181.

[30] C. Cassino, E. Gabano, M. Ravera, G. Cravotto, G. Palmisano, A. Vessières, G. Jaouen, S. Mundwiler, R. Alberto, D. Osella, Inorg. Chim. Acta 357 (2004) 2157-2166.

[31] C. Descôteaux, V. Leblanc, G. Bélanger, S. Parent, É. Asselin, G. Bérubé, Steroids 73 (2008) 1077-1089.

[32] P. Saha, C. Descôteaux, K. Brasseur, S. Fortin, V. Leblanc, S. Parent, É. Asselin, G. Bérubé, Eur. J. Med. Chem. 48 (2012) 385-390.

[33] R. Schobert, G. Bernhardt, B. Biersack, S. Bollwein, M. Fallahi, A. Grotemeier, G.L Hammond, ChemMedChem, vol. 2, John Wiley \& Sons, Ltd, 2007, pp. 333-342. 